\title{
PENINGKATAN EFIKASI DIRI DAN PENURUNAN DEPRESI PADA REMAJA DENGAN COGNITIVE BEHAVIOR THERAPY
}

\author{
Florensa $^{1 *}$, Budi Anna Keliat ${ }^{2}$, Ice Yulia Wardani ${ }^{2}$ \\ 1. STIKes YARSI Pontianak, Kalimantan Barat 78232, Indonesia \\ 2. Fakultas Ilmu Keperawatan Universitas Indonesia, Depok 16424, Indonesia \\ *E-mail: flo_sweety@yahoo.co.id
}

\begin{abstract}
Abstrak
Sekitar 71\% dari 229 remaja SMA di kota Depok, Jawa Barat mengalami depresi. Depresi terjadi karena berbagai faktor diantaranya efikasi diri yang rendah. Cognitive Behavior Therapy (CBT) merupakan terapi yang dilakukan untuk meningkatkan efikasi diri dan mengatasi depresi. Penelitian ini bertujuan untuk mengetahui perubahan efikasi diri dan depresi setelah mendapat CBT. Metode penelitian: quasi eksperimen dengan pre-post test with control group pada penerapan CBT yang dilakukan secara berkelompok. Uji analisis yang digunakan adalah dependen dan independent sample t-Test, chi-square dan pearson product moment. Responden penelitian ini adalah remaja kelas VIII. Sampel penelitian sebesar 72 remaja. Hasil penelitian menunjukkan peningkatan efikasi diri remaja yang mendapat CBT lebih tinggi dibanding remaja yang tidak mendapat CBT, depresi remaja yang mendapat CBT lebih rendah dibandingkan penurunan depresi pada remaja yang tidak mendapat CBT. Peningkatan efikasi diri mempunyai hubungan yang kuat dalam menurunkan depresi pada remaja dengan arah hubungan negatif. CBT direkomendasikan pada remaja dengan efikasi diri rendah dan depresi.
\end{abstract}

Kata kunci: depresi dan Cognitive Behavior Therapy, efikasi diri, remaja

\begin{abstract}
Improved Self-Efficacy and Decrease of Depression in Teenagers with Cognitive Behavior Therapy. Research shows that in the city of Depok, West Java, there is $71 \%$ of 229 high school adolescents with depression. Depression occurs due to various factors such as low self-efficacy. Cognitive Behavior Therapy (CBT) is the treatment carried out to improve the self-efficacy and depression. This study aims to determine the change in self-efficacy and depression after receiving CBT. Research methods: a quasi experimental pre-post test with control group on the application of CBT is done in groups. The analysis used is dependent and independent sample t-test, chi-square and Pearson product moment. The respondents of this study were adolescents class VIII. This sample is 72 adolescents with low self-efficacy and depression. The results showed an increase in self efficacy teen gets CBT significantly higher than adolescents who did not receive CBT, depressed adolescents who received $C B T$ were significantly lower than the decrease in depression in adolescents who did not receive CBT. Increased self-efficacy has a strong relationship in reducing depression in adolescents with a negative direction. CBT is recomended in adolescents with low self-efficacy and depression.
\end{abstract}

Keywords: adolescents, depression and Cognitive Behavior Therapy, self-efficacy

\section{Pendahuluan}

Salah satu bentuk gangguan mental emosional adalah depresi. Menurut Cantwell dan Baker (1991) depresi merupakan masalah yang umum dialami oleh remaja. Depresi pada remaja lebih sulit dikenali dibandingkan depresi yang terjadi pada anak yang lebih kecil. Hal ini dikarena- kan perasaan sedih, kesepian, cemas dan keputusasaan yang dikaitkan dengan depresi dianggap sebagai sesuatu yang normal dalam masa perkembangan remaja. Oleh karena itu Townsend (2009) mengatakan banyak remaja yang mengalami gejala depresi seringkali tidak mendapatkan bantuan karena yang dialaminya dianggap sebagai sesuatu yang wajar di usia tersebut. 
Penelitian di Chicago pada anak sekolah kelas 7 dan 8 menemukan bahwa sepertiga anak sekolah mengalami gejala depresi pada tingkat sedang sampai berat (Sprinthall \& Collins, 1995). Depresi pada remaja dapat diakibatkan oleh berbagai macam faktor, salah satunya terkait dengan pola pikir pada remaja tersebut. Remaja yang depresi cenderung memperlihatkan adanya distorsi pikiran menjadi negatif tentang dirinya sendiri, hidupnya serta masa depan (Gencoz, Voelz, Gencoz, Petit, \& Joiner, 2001 dalam Phares, 2008). Hal ini menunjukkan bahwa penilaian negatif tentang kemampuan diri menyebabkan seseorang dapat mengalami depresi.

Bandura menyatakan persepsi akan kemampuan diri disebut sebagai efikasi diri, dimana efikasi diri memiliki implikasi penting pada perilaku yang dimunculkan. Pernyataan tersebut menjelaskan bahwa persepsi seseorang yang melibatkan fungsi kognitif akan memengaruhi perilaku yang ditampakkan. Penelitian yang pernah dilakukan di Canada oleh Ehrenberg, Cox dan Koopman (1991) pada remaja memperlihatkan bahwa ada hubungan negatif antara efikasi diri dengan depresi. Penelitian tersebut diperkuat dengan studi longitudinal yang dilakukan oleh Scott dan Dearing (2012) pada remaja sekolah menengah di Amerika Utara yang menemukan bahwa efikasi diri yang tinggi dapat menurunkan risiko depresi. Penelitian-penelitian tersebut memperlihatkan bahwa remaja yang mempunyai efikasi diri yang rendah mempunyai persepsi negatif terhadap kemampuannya mengatasi stressor sehingga akan lebih mudah mengalami depresi dibanding remaja yang mempunyai efikasi diri yang tinggi.

Manifestasi depresi pada remaja dapat menimbulkan berbagai dampak seperti terganggunya fungsi sosial, mengalami kesulitan untuk berkonsentrasi, mengalami ketidakberdayaan, hingga tindakan bunuh diri. Di Amerika, selama tiga dekade terakhir angka bunuh diri pada individu berusia 15 tahun sampai 24 tahun meningkat tiga kali lipat dan merupakan penyebab ke- matian nomor tiga dikelompok usia tersebut (National Center for Health Statistic, 2007 dalam Townsend, 2009). Hal ini terjadi karena terdapat peningkatan insiden depresi pada populasi ini (Roy dalam Videbeck, 2008). Meskipun tidak semua remaja yang depresi mencoba bunuh diri, akan tetapi depresi dikatakan sebagai faktor yang paling banyak disebut sebagai faktor yang berkaitan dengan bunuh diri (Santrock, 2003).

Di Indonesia prevalensi bunuh diri pada anak dan remaja dalam satu tahun antara $1,7-5,9 \%$ dan diperkirakan $12 \%$ kematian pada umur tersebut diakibatkan oleh bunuh diri (Ulmila, 2008 dalam Keliat, Tololiu, \& Daulima, 2010). Penelitian yang dilakukan pada siswa SMA di kota Depok diketahui dari 229 remaja SMAN kota Depok ditemukan $71 \%$ diantaranya mengalami depresi yang juga berisiko melakukan tindakan bunuh diri (Keliat et al., 2010). Datadata tersebut menunjukkan bahwa walaupun depresi tidak selalu merupakan alasan remaja untuk bunuh diri akan tetapi risiko bunuh diri pada remaja yang mengalami depresi juga cukup tinggi.

Sejauh ini penanganan depresi dilakukan melalui konseling, psikoterapi dan pemberian obat, walaupun penyembuhan depresi melalui obat bagi anak-anak masih kontroversial. Cara ini merupakan penanganan yang efektif bagi $70 \%$ dari mereka yang menderita depresi. The National Institute for Health and Clinical Exelence/ NICE (dalam Solomando, Kendall $\&$ Whittington, 2008) menyusun panduan penatalaksanaan penanganan depresi pada anak dan remaja. NICE merekomendasikan intervensi yang perlu diberikan adalah intervensi psikososial yang salah satunya adalah Cognitive Behavior Therapy (CBT).

CBT diberikan sebagai salah satu upaya preventif. Penelitian yang dilakukan oleh Hayes, 2004; Possel, Horn, Groen dan Hautzinger, 2004 (dalam Phares 2008) menunjukkan CBT berbasis sekolah dapat mencegah peningkatan depresi pada remaja. Penelitian serupa juga 
memperlihatkan bahwa program Cognitive Behavior Therapy berbasis sekolah mempunyai efek yang kuat terhadap penurunan depresi pada remaja bila dilakukan oleh psikolog dan peneliti (Phares, 2008).

Berdasarkan pemaparan di atas maka penulis tertarik untuk melakukan penelitian yang bertujuan untuk mengetahui pengaruh CBT terhadap efikasi diri dan depresi pada remaja.

\section{Metode}

Penelitian ini menggunakan metode kuantitatif dengan disain Quasi Experimental Pre-Post Test with Control Group dan intervensi Cognitive Behavior Therapy (CBT). Pengambilan sampel menggunakan teknik simple random sampling. Penelitian ini dilakukan untuk mengetahui perubahan efikasi diri dan depresi pada remaja setelah pemberian CBT. Responden berjumlah 72 orang yang terdiri atas 38 orang pada kelompok kontrol dan 34 orang pada kelompok intervensi. Pengumpulan data dilakukan dengan menggunakan kuesioner untuk data karakteristik responden. Modul CBT yang digunakan dalam penelitian ini merupakan pengembangan dari penelitian sebelumnya dan sudah dilakukan uji expert validity oleh pakar keperawatan jiwa FIK-UI. Analisis statistik yang dipergunakan adalah univariat, bivariat dan korelasi dengan tampilan dalam bentuk tabel dan distribusi frekuensi.

\section{Hasil}

Hasil penelitian ini menunjukkan bahwa ratarata efikasi diri dan depresi pada remaja sebelum terapi secara berurutan adalah17,9 dengan rentang 11-23 dan 19,72 dengan rentang nilai 15-23. Hasil analisis setelah dilakukan CBT memperlihatkan bahwa rata-rata efikasi diri remaja yang mendapat CBT adalah 31,26 , sementara pada remaja yang tidak mendapat CBT adalah 17,03. Hasil uji statistik menunjukkan adanya perbedaan yang bermakna $(\mathrm{p}<0,005)$ antara efikasi diri pada ke- lompok intervensi dengan kelompok kontrol. Rata-rata depresi setelah remaja mendapatkan CBT adalah 14,50 dan pada remaja yang tidak mendapatkan CBT adalah 18,79. Hasil uji statistik menunjukkan adanya perbedaan yang bermakna ( $p>0,005)$ antara depresi remaja yang mendapat CBT dengan remaja yang tidak mendapat CBT.

Berdasarkan hasil analisis diketahui bahwa ada hubungan antara efikasi diri dengan depresi $(\mathrm{p}=0,001)$ dimana kekuatan hubungan dua variabel adalah kuat, dengan arah negatif yang menunjukkan bahwa semakin tinggi efikasi diri maka semakin rendah depresi.

\section{Pembahasan}

Hasil penelitian menunjukkan adanya peningkatan yang bermakna pada efikasi diri setelah mendapatkan CBT pada kelompok intervensi, sebaliknya pada kelompok kontrol terjadi penurunan yang tidak bermakna. Hasil penelitian ini sesuai dengan hasil penelitian Hyun, Chung dan Lee (2005) yang menemukan bahwa remaja yang mempunyai efikasi diri yang rendah setelah mendapat CBT memperlihatkan peningkatan efikasi diri yang signifikan dibanding remaja pada kelompok yang tidak mendapat CBT. Penelitian lain yang juga mendukung adalah penelitian Kumar dan Sebastian (2011) pada remaja sekolah di India yang mana hasil penelitiannya menunjukkan bahwa CBT mempunyai implikasi dalam memperbaiki efikasi diri.

Hasil penelitian ini mengidentifikasi bahwa efikasi diri pada kelompok yang tidak mendapat CBT mengalami penurunan meskipun tidak bermakna. Menurut peneliti hal ini dapat diakibatkan karena jarak antara pre dan post test cukup dekat sehingga dimungkinkan responden masih mengingat jawaban yang diberikan pada saat post test. Selain itu pada saat dilakukan penelitian, responden sedang mengikuti ujian semester dan hasil ujian memperlihatkan bahwa sebagian besar dari responden memiliki hasil ujian yang kurang memuaskan. 
Menurut Bandura dan Beck kognitif individu menjadi rentan bila mereka memiliki gaya pesimis atau disfungsi sikap tentang diri mereka dan lingkungan. Ketika individu tersebut dihadapkan pada pengalaman hidup yang tidak menyenangkan, seperti kegagalan di sekolah maka mereka berisiko untuk membuat kesimpulan yang negatif tentang diri mereka yang pada akhirnya akan mengembangkan perasaan putus asa dan depresi (dalam Ghaderi \& Salehi, 2011).

Berdasarkan konsep yang dijelaskan di atas, jelas bahwa efikasi diri dipengaruhi oleh kognitif sehingga pada responden yang tidak mendapat CBT maka tidak akan terjadi perbaikan dari distorsi kognitif yang dialami. Kemudian dengan adanya pengalaman hidup yang tidak menyenangkan akan membuat individu makin memandang dirinya secara negatif.

Penelitian ini menunjukkan bahwa CBT mempunyai pengaruh dalam menurunkan depresi, dimana setelah pemberian CBT, pada kelompok intervensi terdapat penurunan rata-rata skor depresi secara bermakna daripada kelompok kontrol yang tidak mengikuti CBT. Hal ini memperlihatkan bahwa CBT yang diberikan mampu menurunkan depresi dibandingkan dengan remaja yang tidak mendapatkan CBT.

Hal ini juga sesuai dengan penelitian Rossello, Bernal, dan Rivera-Medina (2008) yang menemukan bahwa CBT dapat menurunkan depresi pada remaja. Penelitian lain juga menjelaskan bahwa CBT efektif untuk menurunkan depresi pada remaja di sekolah dibandingkan dengan relaksasi dan self-modeling interventions yang dilakukannya dalam penelitian tersebut.

Inti dari CBT adalah merubah persepsi dan cara menginterpretasikan dan hubungan arti tertentu dari kejadian dalam kehidupan seharihari. Jadi CBT merupakan suatu terapi yang dapat membantu individu membuat keputusan dengan mengubah pikiran dan perilakunya yang negatif menjadi positif dan berfokus pada keadaan atau masalah yang dihadapi saat ini.
Terapi CBT yang dilaksanakan secara berkelompok pada remaja mempunyai keuntungan yang lebih daripada terapi yang dilakukan secara individu. Untuk mengubah perilaku seseorang perlu diberikan stimulus. CBT yang dilakukan secara berkelompok akan memberikan support system pada remaja karena mereka merasa memiliki masalah yang sama, remaja akan belajar mengamati bagaimana orang lain berperilaku dan mengkaji sikap serta reaksi melalui interaksi dengan berbagai macam orang. Selain itu remaja dapat belajar dari pengalaman positif dari teman sekelompok dalam terapi yang dapat digunakan untuk mengatasi distorsi pikiran maupun perilaku maladaptif yang muncul. Bandura dan Walter, 1977 (dalam Nies \& McEwen, 2001) mengembangkan teori social learning theory dimana seseorang dalam kontak sosial akan mempelajari tingkah laku orang lain kemudian juga akan melakukan atau meniru tingkah laku orang tersebut.

Pada penelitian ini diketahui bahwa setelah mendapatkan CBT terjadi penurunan depresi. Penurunan yang terjadi pada responden tidak sampai pada tahap dimana depresi menjadi tidak ada. Menurut peneliti hal ini dapat diakibatkan oleh waktu pre dan post test yang cukup dekat sehingga belum bisa dilihat secara optimal efek dari terapi yang dilakukan dan selain itu juga pertemuan dari sesi CBT yang cukup singkat yang hanya dilakukan dalam 5 kali pertemuan. Penelitian Rossello, et al., (2008) menyatakan pada remaja depresi masih banyak yang tidak memperlihatkan respon terhadap CBT dengan dosis standar yaitu 12 sesi sehingga pada penelitian tersebut sesi dalam terapi ditambah menjadi 16 sesi. Selain itu hasil pada penelitian tersebut dikatakan bahwa responden terus menunjukkan perbaikan gejala depresi beberapa bulan setelah terapi diberikan (1 tahun post treat-ment). Penelitian Solomando, Kendall dan Whittington (2008) menyatakan berdasarkan penelitian-penelitian yang telah dilakukan sebelumnya memperlihatkan bahwa CBT dengan 8-16 sesi dengan durasi 20-60 menit yang dilakukan selama 5-8 
minggu memperlihatkan hasil yang lebih baik. Hal ini menunjukkan bahwa dengan panjangnya waktu terapi, akan memberikan waktu yang cukup pada responden untuk mampu menginternalisasikan terapi yang diberikan ke dalam kehidupannya sehingga akan menurunkan depresi secara optimal.

Penelitian Rossello, et al. (2008) mengindikasikan bahwa CBT yang diberikan dalam sesi yang pendek pada penelitian ini belum mampu untuk menurunkan depresi sampai pada tahap tidak depresi sehingga perlu dilakukan pemberian terapi lainnya yang memungkinkan remaja mampu mengontrol stress yang berdampak terhadap terjadinya depresi. Penelitian yang dilakukan pada remaja sekolah menengah atas di Kota Depok memperlihatkan bahwa terjadi penurunan tingkat depresi pada remaja yang mendapat latihan pertahanan diri terhadap stress (Keliat, Tololiu, \& Daulima, 2010). Latihan pertahanan diri terhadap stres dapat dijadikan terapi kombinasi dengan CBT sehingga dapat menurunkan depresi dan risiko bunuh diri yang lebih baik dibandingkan dengan hanya pemberian CBT.

Hasil penelitian ini menunjukkan bahwa terdapat hubungan yang kuat antara efikasi diri dengan depresi dimana arah hubungannya negatif. Hal ini dapat disimpulkan bahwa peningkatan efikasi diri akan meningkatkan kemampuan individu dalam memandang dirinya secara positif. Selain itu dapat berdampak pula pada kemampuan individu untuk meningkatkan kemampuannya dalam mengatasi stressor dalam kehidupannya dan memandang stressor sebagai suatu tantangan yang harus dihadapi.

Penelitian lain Ehrenberg, Cox dan Koopman (1991) mendukung hasil penelitian ini dimana dinyatakan bahwa efikasi diri mempunyai hubungan penting terhadap depresi pada remaja. Penelitian lain oleh Ghaderi dan Salehi (2011) menjelaskan bahwa efikasi diri mempunyai korelasi dengan depresi. Tabassum dan Rehman (2005) juga menyatakan bahwa efikasi diri yang tinggi pada anak menjadi faktor protektif melawan terjadinya depresi dan efikasi diri yang rendah akan membawa mereka kedalam kondisi depresi.

Efikasi diri akan memengaruhi bagaimana cara berpikir seseorang sehingga pada individu yang memiliki efikasi diri yang tinggi akan memandang masalah sebagai sebuah tantangan karena individu tersebut mempunyai keyakinan diri yang tinggi akan kemampuannya dalam mengatasi masalah tersebut. Sebaliknya individu dengan efikasi diri yang rendah cenderung untuk tidak memiliki keyakinan diri dan memandang masalah sebagai hambatan sehingga hal tersebut mengakibatkan kecemasan. Kecemasan yang terjadi dalam jangka waktu yang lama akan berdampak terhadap timbulnya depresi.

\section{Kesimpulan}

Populasi pada penelitian ini adalah remaja yang duduk di kelas VIII di SMPN 15 dan SMPN 18 Kota Bogor yang berjumlah 608 orang. Sampel 72 orang yang terbagi menjadi 38 orang di kelompok intervensi dan 34 orang lainnya di kelompok kontrol. Efikasi diri remaja pada kelompok intervensi sebelum dan setelah mendapat CBT mengalami peningkatan yang bermakna sedangkan kelompok kontrol yang tidak mendapat CBT mengalami penurunan yang tidak bermakna.

Depresi pada remaja di kelompok intervensi mengalami penurunan yang bermakna setelah mendapatkan CBT sedangkan pada kelompok kontrol yang tidak mendapatkan terapi juga mengalami penurunan akan tetapi tidak bermakna. Hubungan antara efikasi diri dengan depresi setelah mendapatkan CBT adalah bermakna dengan tingkat korelasi yang kuat. Arah hubungan menunjukkan hubungan yang negatif dimana peningkatan efikasi diri akan berdampak pada penurunan depresi pada remaja $(\mathrm{SH}, \mathrm{HR}, \mathrm{NN})$. 


\section{Referensi}

Ehrenberg, M.F., Cox., D.N., Koopman, R.F., (1991). The relationship between selfefficacy and depression in adolescents. Adolescence, 26 (102), 361-74. Diperoleh dari https://www.ncbi.nlm.nih.gov/pubmed /1927668

Ghaderi, A.R., \& Salehi, M. (2011). A study of the level of self-efficacy, depression and anxiety between accounting and management students: Iranian evidence. Diperoleh dari http://www.idosi.org/wasj /wasj12(8)/28.pdf.

Hyun, M.S., Chung, H.I., Lee, Y.J. (2005). The effect of cognitive-behavioral group therapy on the self-esteem, depression, and selfefficacy of runaway adolescents in a shelter in South Korea. Applied Nursing Research, 18 (3), 160-166. DOI: 10.1016/j.apnr.2004. 07.006. Diperoleh dari http://www.ncbi. nlm.nih.gov /pubmed/16106334.

Keliat, B.A., Tololiu, A.T., \& Daulima, N.H.C. (2010). Efektifitas pertahanaan diri terhadap stress pada remaja risiko bunuh diri di Depok. (Tesis, tidak dipublikasikan). Program Studi Magister Fakultas Ilmu Keperawatan Universitas Indonesia, DepokJawa Barat, Indonesia

Kumar, V., \& Sebastian, L. (2011). Impact of CBT on self efficacy and academic achievement in adolescent students. Journal of the Indian Academy of Applied Psychology, 37, 134-139. Diperoleh dari http://www.jiaap.org/Listing_Detail/Logo/cf 053c4c-b0ab-47de-af77-b8d507 cad301.pdf.

Nies, M.A., \& McEwen, M. (2001) Community health: Promoting the health of populations (3th Ed.). Philadelphia: W.B. Saunders Company.
Phares, V. (2008). Understanding abnormal Child Psychology (2nd Ed.). USA: Jhon Wiley \& Sons Inc.

Rosselló, J., Bernal, G., \& Rivera-Medina, C. (2008). Individual and group CBT and IPT for Puerto Rican adolescents with depressive symptoms. Cultur Divers Ethnic Minor Psychol, 14 (3), 234-45. doi: 10.1037/10999809.14.3.234. Diperoleh dari https://www. ncbi.nlm.nih.gov/pubmed/18624588

Santrock, J.W. (2003). Remaja. Jilid I. Jakarta: Erlangga.

Solomando, A.M., Kendall, T., \& Whittington, C.J. (2008). Cognitive behavior therapy for children and adolescents. Current Opinion in Psychiatry, 21 (4), 332-337. doi: 10. 1097/YCO.0b013e328305097c. Diperoleh dari https://www.ncbi.nlm.nih.gov/pubmed /18520736

Sprinthall, N.A., \& Collins,W.A (1995). Adolescent Psychology A developmental View (3rd Ed.). New York: McGraw-Hill Inc.

Tabassum, U., \& Rehman. G., (2005). The relationship between self-efficacy and depression in physically handicapped children. Journal of Pakistan Psychiatric Society, 2 (1), 37-40. Diperoleh dari http:// www.jpps.com.pk/article/therelationshipbet weenselfefficacyanddepressioninphysicallyh andicappedchildren_2239.html

Townsend, M.C. (2009). Psychiatric mental health nursing: Concept of care in avidence based practice (6th Ed.). Philadelphia: F.A. Davis Company.

Scott, W.D., \& Dearing, E. (2011). A longitudinal study of self efficacy and depressive symptom in youth north american plain tribe. Development \& Psychopathology 
Journal, 24 (2), 607-622. doi: 10.1017/ S0954579412000193. Diperoleh dari https:// www.ncbi.nlm.nih.gov/pubmed/ 22559134

Videbeck, S.L. (2008). Buku Ajar Keperawatan

Jiwa. Jakarta: Penerbit Buku Kedokteran EGC. 